\title{
THE CONSTRUCTIVE WORK OF THE AMERICAN ARMY
}

\author{
By Leonard Wood, \\ Major-General, United States Army.
}

I want to say a word to you about the life-saving work of our country in the tropics through its principal agent, the Army, an agent which is more generally misunderstood in this country, perhaps, than any other branch of the government, an agent whose life-saving work has been of infinite value to mankind and to the nation. We in America understand too little the work of the Army, too little of what it has done to save life, and we talk too much of it as a destructive force. There are very few who realize or know that in ten peaceful Fourth of July celebrations of a war finished about 135 years ago we killed some 1,800 people, mostly young boys, and wounded some 35,000 and odd, also mostly boys and young children. The killed of those ten peaceful single day celebrations about equal all the killed of the Spanish war and the Philippine Rebellion and the Indian wars of the preceding ten years. And the wounded of those ten peaceful single day celebrations, were, roughly, seven times the wounded of all those wars.

War is by no means the greatest cause of death among the human race. Typhoid fever every year in this country, until some doctors discovered how to control it, cost 40,000 lives. That number almost equals the loss of life on the battlefield of all our wars, excluding that of the Civil War, beginning with the foundation of the Republic. Our industrial accidents each year amount to some 462,000 , with a death list of nearly 80,000 . You take little interest in correcting the causes and conditions which make such things possible, but talk a great deal about war, of which you know extremely little. Seventy-nine thousand lives a year, or a number of lives equal to the losses of any two average years of the Civil War, and more than the total loss in battle of all our other wars, and yet you don't think much about it.

We have heard here tonight that international peace can best be secured by doing away with patriotism, and that there is no such thing as a national conscience. So far as America goes, I claim that there 257 
is such a thing as a national conscience, and a very strong and a very active one. On some questions it is not keenly alive because their importance has not been brought to the attention of the people, but once brought to their attention and placed squarely before them in such a way that they can understand it, the national conscience becomes active. The best type of national conscience will only be found where the training of individuals has been broad and sound. The national conscience as a whole consists, as it were, of the collective conscience of individuals, consequently it depends upon individual training and individual morals. International congresses can do very little if the training of the people has been unsound and they are wanting in proper moral principles. It is the education of the individual, after all, which counts, and this education must begin in the home. If we have decent, moral boys and girls and sound teaching in the home we shall have good morals in public life. You will have a quiet, strong, God-fearing nation which, while not aggressive, will, I hope, always be proud of its flag and all that it stands for, willing to defend its interests when attacked, and, while seeking to avert war through justice and fair dealing, will nevertheless be ready and willing to resist injustice and accept war rather than peace with dishonor or peace which involves conditions worse than war.

We must always remember one thing: we are too prone in this country to, figuratively speaking, pat ourselves on the back as being the most intellectual and the most advanced people. Our opinion in this matter is not generally accepted by foreign countries. Do you know that our criminal rate is the highest of any of the great Christian nations? I doubt if you do. Our murder rate is several times that of Switzerland, where general military training to defend the country seems not to have debauched the youth, if we can judge by the criminal rate.

Now, when we took over our trust in Cuba, the conscience of the American people decreed that we should not exploit that island, but that we should do all that we could to build up and better the people. For four years the work was entirely in the hands of the Army, acting as an agent of reconstruction. The courts and municipal and provisional governments of Cuba ran without interference. The record for the prompt punishment of crime was better than in any state of the Union. The death-rate in that Island was re- 
duced from one of the largest in the world to one of the smallest. The wonderful results which grew out of the work and discoveries of Dr. Walter Reed and his associates, who nobly and generously gave health and even life itself to the work, have been applied to the control of yellow fever in our southern states, in Central American and northern South American countries, as well as in Cuba and the islands of the West Indies, and have brought untold blessings to those lands through the doing away with their most terrible scourge-the much dreaded yellow fever. The tropics have been made a white man's country so far as this disease is concerned. The number of lives saved in the tropical lands every year are many times the number of those lost during the war, and the saving in our own country has been very great, not only in life but in money, exceeding in all probability many times the cost of the war, in each. Those who are business men can appreciate what a quarantine extending from the mouth of the Rio Grande sometimes almost to the Potomac and away up the Mississippi above Memphis, cost the people of the South. All freight was tied up, all movement of individuals greatly curtailed-business practically paralyzed. Not only was its effect far-reaching in the case referred to, but out of its results came the possibility of another great work, the Panama Canal. Magnificent as has been the engineering work and its conduct by General Goethals and his assistants, in my opinion it never would have been possible to build the canal had it not been for the discovery of Reed and his associates and the application of this discovery to Panama under the direction of the present SurgeonGeneral, Doctor Gorgas, who for a long time had charge of yellow fever work in Havana and established there methods of handling it which were later applied in Panama with great success. The sanitary work of Gorgas in Panama made it possible for that great undertaking to be conducted under health conditions which were exceeded in few portions of the United States. When we speak of what has been accomplished in the control of yellow fever you must remember that the accomplishment is for all time and for all people living in the tropical and semi-tropical region of the western hemisphere.

In Porto Rico one of our young medical officers, Dr. Bailey K. Ashford, interested himself in what is known as tropical anemia, or hookworm disease. He established the method of its control, 
established a systematic campaign against it throughout Porto Rico, and finally reduced the death-rate from this disease alone in this little island with its million people, some 1,400 per year. Here again is a great sanitary discovery growing out of our war with Spain, and like yellow fever, it is a discovery which is of immense value to tropical and semi-tropical peoples. What we for a long time considered as tropical laziness or shiftlessness is traceable very largely to the effects of this disease, so that the discovery of its cause and the establishment of a method of treatment and control means the revitalizing of the people of these tropical countries, as well as of the people of a considerable portion of our southern states. A recent estimate by planters in Porto Rico places the increased efficiency of their men, incident to doing away with this disease, as high as 60 per cent. It is hard to estimate the economic value of a discovery of this kind, and it is still more difficult to appreciate the far-reaching effect in the way of the saving of human life and adding to the measure of human contentment and happiness.

You are no doubt familiar with the assembling of troops on the Mexican border, and that when first assembled a great deal of tyhoid existed on the Mexican side of the river. This made it necessary to take up the systematic control of typhoid through the use of a typhoid serum beginning to be used in the British Army. It was taken up by our medical officers with such success that last year, with something over 100,000 men scattered all over the world, there was not a death from typhoid in the Army. Contrast this with the conditions at Chickamauga when there were over 1,500 cases of typhoid in that camp alone, with a huge death-rate.

Again, in the Philippines, our medical work incident to the occupation of those islands has done away with beri beri. This was not the work of the Army, but was accomplished by the medical officers connected with the Insular government, working under the direction of the Insular Bureau of the War Department.

Other great results have been accomplished in the control of malaria and the general betterment of sanitary conditions. In fact, the whole work in these tropical possessions has tended to the betterment of conditions under which people live, both from the standpoint of government and the standpoint of sanitation. The improvements in sanitation have been more generally appreciated than in any other department of our work, and they have been 
accomplished without any exploitation of the country and have undoubtedly resulted in building up bonds of lasting sympathy between the people who have come under our control and ourselves, for they must appreciate in their hearts the great work which has been done for them.

So, when you think of our Army and its work, do not think of it always as an aggregation of fighting people, bent only on fighting, but remember that it is one of the great constructive life-saving agencies of the Republic. Its work has been continuous from the earliest days. In addition to the great work of the Spanish war and the subsequent colonial period, and preceding it, it was engaged for years in opening up the West, controlling the Indian situation, safeguarding the mail routes, keeping roads open, aiding in surveys, conducting many of them, in fact. It was the advance guard of civilization and the protecting agent of people crossing the great unsettled section between the Pacific slope and the eastern frontiers. In recent years the control of conditions resulting from Mississippi floods has been handled by the Army-handled so quietly and so effectively that few have ever heard that at times 200,000 people were being taken care of each day. This work was done quietly by young officers who were trained to be obedient, to do things as told and when told, to do them promptly, to get things done. This is possible when you have conditions of discipline and training. Remember that the Army is not working for a large army, we are working for an efficient one, and a system which will make it capable of expansion in time of need. We believe in a good militia, supported like the regular Army, by good reserves, and a system which will make military training more general among the people, believing that reasonable preparation is the best insurance against war.

There is no more democratic element in this country than your Army and your Navy, and no class which stands abuse or misrepresentation with less resentment than the two sister services. We know you do not understand us, our purpose or work, but don't constantly refer to armed force as a destructive element. You might as well say that your police force is a destructive element simply because it is trained to do certain things with force if it has to.

Another idea you must get out of your heads is that soldiers and sailors are fond of fighting for its own sake. You might just as well say that the life-saving service down on the coast in winter 
is praying for gales of wind and rough work at sea simply because they are trained to it. The Army and Navy are willing to do cheerfully what the nation decrees in this line because they are the people to do it. That is as it should be. Look at the constructive work the nation has done through its military arm (Army and Navy), and remember that it is always subordinate to the will of the nation, that it is without unworthy ambition, that it hates militarism, that it is simply your agent. When you turn to the work of your country in its dealings with the tropical peoples who came under our control as a result of the war of 1898 , remember that none of these countries has been exploited for our profit, that their people have received great benefit as the result of our control, and that they are living under far better conditions as to education, material comforts and health than ever before. 